\title{
Hubungan Kepribadian Guru dan Sosial Ekonomi OrangTua Terhadap Motivasi Belajar Pada Siswa Madrasah Tsanawiyah
}

\author{
M.Saipul Watoni \\ STIT Palapa Nusantara \\ tony_pedros@rocketmail.com
}

\begin{abstract}
Abstrak: Penelitian ini merupakan penelitian deskriptif dengan menggunakan pendekatan kuantitatif. Populasi penelitian ini adalah kelas VIII MTs. NW Selebung dengan sampel penelitian sebessar 22 siswa kelas VIIIA MTs NW Selebung yang diambil dengan tehnik random sampling. Pengumpulan data keribadian guru dan sosial ekonomi orang tua dan motivasi siswa menggunakan aket menyebarkarkan angket. Data dianalisis dengan tehnik analisis statistik dan regresi linier berganda. Hasil penelitian menunjukkan bahwa: 1) variabel kepribadian guru di MTs NW Selebung termasuk kategori tinggi dengan nilai mean $(\mathrm{M})=46,59$ dan standar deviasi $(\mathrm{SD})=3,17$ dan variabel sosial ekonomi orang tua di MTs NW Selebung termasuk kategori tinggi dengan nilai mean $(\mathrm{M})=44,95$ dan standar deviasi (SD) $=4,68$ sedangkan variabel motivasi belajar MTs NW Selebung termasuk kategori tinggi dengan nilai mean $(\mathrm{M})=48,5$ dan standar deviasi $(\mathrm{SD})=4,22.2$ ) variabel kepribadian guru di MTs NW Selebung memiliki skor data normal dengan nilai $\mathrm{X}^{2}$ hitung $=4,928$ dan variabel sosial ekonomi orang tua di MTs NW Selebung memiliki skor data normal dengan nilai $\mathrm{X}^{2}$ hitung $=2,421$ sedangkan variabel motivasi belajar siswa di MTs NW Selebung juga memiliki skor data normal dengan nilai $\mathrm{X}^{2}$ 1,457.termasuk kategori tinggi dengan nilai mean $(\mathrm{M})=$ 47,5 dan standar deviasi $(\mathrm{SD})=4,22$ dengan $\mathrm{X}^{2}$ tabel $=11,070$ pada taraf kepercayaan 59\%. 3) bahwa terdapat hubungan yang signifikan antara kepribadian guru dan sosial ekonomi orang tua terhadap motivasi belajar siswa di MTs. NW Selebung. Hal ini dapat dilihat dari hasil perhitungan uji hipotesis dengan menggunakan regresi ganda dengan nilai $\mathrm{RX}_{1} \mathrm{X}_{2} \mathrm{Y}=0,29$ kemudian dikonsultasikan dengan $\mathrm{F}$ hitung sebesar $(7,73)$ dan F-tabel $=3,81$ pada taraf kepercayaan $5 \%$ dan $\mathrm{dk}$ pembilang $(\mathrm{m})=2 \mathrm{dan} \mathrm{dk}$ penyebut $(\mathrm{n}-\mathrm{m}-1)=19$ atau dengan kata lain F-hitung $>$ F-hitung atau $(7,73>3,81)$ dengan arah regresi $\mathrm{y}=$ $44,9+0,009 \mathrm{X}_{1} \cdot+0,05 \mathrm{X}_{2}$.
\end{abstract}

Kata kunci: Kepribadian guru, sosial ekonomi orang tua 


\section{Pendahuluan}

Saat ini pelajaran ekonomi sudah merupakan hakekat dari kehidupan manusia terutama pada era globalisasi dan informasi ini. Pelajaran ekonomi sebagai sarana pengembangan berpikir logis dan sistematis adalah menjadi fundamen pengembangan ilmu pengetahuan dan tekologi, membiasakan anak berpikir matematis akan memudahkan siswa untuk berpola pikir yang logis, sistematis dan rasional sebagai suatu keharusan terutama dalam menyongsong era modern yang menuntut kompetisi dalam meraih serta memanfaatkan peluang yang ada. Melihat akan pentingnya peran penguasaan pelajaran ekonomi tersebut tetapi di kalangan siswa bahkan juga pelajaran masyarakat justru masih terdapat pandangan bahwa belajar ekonomi merupakan suatu pelajaran yang membosankan.

Kebosanan terhadap pelajaran ekonomi adalah merupakan suatu fakta, problema ini biasanya terjadi dengan situasi, kondisi, dan pengalaman belajar ekonomi di dalam kelas, seperti kemampuan guru menggunakan strategi atau metode pengajaran strategi atau metode guru yang kurang baik akan mempengaruhi balajar siswa yang kurang baik pula strategi atau metode mengajar belajar kurang baik terjadi karna guru kurang persiapan, kurang menguasai bahan dan kadang kuru terlalu cepat menerangkan sehingga guru tersebut menyajikannya kurang jelas, sehingga siswa kurang senang terhadap pelajarannya. Akibatnya siswa malas untuk belajar yang pada akhirnya mempengaruhi proses belajar siswa (Sametto, 2003: 65).

Seorang guru yang berhasil dituntut untuk berlaku adil sehinga terbina suasana emosional yang menyenangkan dalam proses belajar mengajar. sikap guru dalam menghadapi siswa yang melangar peraturan sekolah hendaknya tetap sabar dan tetap bersahabat dengan suatu keyakinan bahwa salah satu masalah yang di hadapi guru untuk menyelenggarakan pengajaran adalah bagaimana guru memberikan semangat untuk menumbuhkan motivasi dalam diri siswa

Dalam proses belajar, anak juga membutuhkan pengertian dari orang tua yang berupa motivasi bila anak lebih cendrung bermain-main pengertian dari orang tua pula akan memberikan dampak positif bila anak sedang belajar dengan kata lain anak diberikan kesempatan belajar tanpa harus diganggu dengan tugas -tugas rumah.

Salah satu indikator pendidikan yang berkualitas adalah perolehan hasil belajar siswa sangat dipengaruhi oleh kegiatan proses belajar mengajar ini terdapat 
beberapa faktor yang merupakan penentu lancar atau tidaknya kegiatan proses belajar mengajar. (Sadia, 2002:6) faktor-faktor itu antara lain:

1. Instrumen input, yaitu: kurikulum, perpustakaan, guru dan sebagainya;

2. Raw input, yaitu: siswa, motivasi, cara belajar dan sebagainya;

3. Environment input, yaitu: lingkungan fisik dan sosial budaya.

Dari ketiga faktor utama yang mempengaruhi lancar atau tidaknya proses pembelajaran tersebut di atas, dalam penelitian ini difokuskan pada usaha pembelajaran yang dilakukan oleh guru di dalam kelas, karena keberhasilan pembelajaran, dalam arti tercapainya tujuan-tujuan instruksional sebagian besar sangat bergantung pada kemampuan guru.

Perjalanan pendidikan tidak selalu seperti yang di harapkan.berbagai masalah pendidikan timbul terlebih masalah motivasi belajar siswa yang rendah khususnya dalam mata pelajaran ekonomi dan permasalahan ini memerlukan pemecahan yang harus di tandatangani oleh semua pihak baik itu siswa, orang tua, guru, baik guru bidang studi maupun guru bimbingan konsling dan juga wali kelas masing-masing. Dari alasan yang dikemukakan di atas maka dipandang perlu untuk dilakukan penelitian tentang "Hubungan Keperibadian Guru dan Sosial Ekonomi Orang Tua Terhadap Motivasi Belajar Siswa pada Siswa Madrasah Tsanawiyah”.

\section{KAJIAN TEORI}

\section{Kepribadian Guru}

Pembahasan mengenai kepribadian guru berikut ini akan dibahas mengenai: (a) pengertian kepribadian guru, (b) aspek-aspek kepribadian guru, (c) faktor-faktor yang mempengaruhi kepribadian.

a. Pengertian Kepribadian Guru

Menurut asal katanya kepribadian atau personality berasal dari bahasa Latin personare, yang berarti mengeluarkan suara (to sound throubg). Istilah ini digunakan untuk mengujudkan suara dari percakapan seorang pemain sandiwara melalui topeng (masker) yang dipakainya.

Kepribadian mengandung pengertian yang kompleks. Kepribadian atau personality itu tidak dinamis, tidak statis atau tetap saja tanpa perubahan. Ngalim Purwanto dalam Indring Fispiana (2001 : 12) menjelaskan tingkah laku yang 
terintegrasi dan merupakan interaksi antara kesanggupan-kesanggupan bawaan yang ada pada individu dengan lingkungannya ia bersifat psikofisik, yang berarti baik faktor jasmaniah maupun rohaniah individu itu bersama-sama memegang peranan dalam kepribadian ia bersifat unik artinya kepribadian seseorang sifatnya khas, mempunyai ciri-ciri tertentu yang membedakannya dari idnividu ke individu lain..

b. Faktor-Faktor yang Mempengaruhi Kepribadian

Faktor-faktor yang mempengaruhi perkembangan dan kepribadian itu dapat dibagi sebagai berikut: (1) faktor biologis, (2) faktor sosial, dan (3) faktor kebudayaan

\section{Peranan Guru dalam Mendidik Siswa dalam Pelajaran Ekonomi}

Peran guru secara umum dalam proses belajar mengajar ekonomi adalah sesuai dengan ajaran yang terkenal dari Ki Hajar Dewantara yang berbunyi "Ing Ngarso Sung Tulodo, Ing Madyo Mangun Karso, Tut Wuri Handayani” yang kurang lebih berarti: jika di depan menjadi contoh, jika di tengah-tengah membangkitkan hasyrat untuk belajar dan jika di belakang mengikuti dengan awas.

a. Penciptaan Hubungan Guru dengan Murid yang Baik

Menciptakan hubungan yang baik dengan siswa dalam proses belajar mengajar adalah termasuk merupakan kewajiban utama bagi guru. Berkaitan dengan hal ini Thomas Gordon dalam Indring Fispiana (2001 : 18) berpendapat bahwa:

Hubungan guru dengan murid dikatakan baik apabila hubungan itu memiliki sifat-sifat:

(1) keterbukaan, baik guru maupun murid saling bersifat jujur dan membuka diri satu sama lain;

(2) saling ketergantungan antara yang satu dengan yang lain;

(3) tanggap bilamana seseorang tahu bahwa dia dinilai oleh orang lain;

(4) kebebasan yang meperbolehkan setiap orang tumbuh dan mengembangkan keunikannya, kreatifitasnya and kepribadi-annya;

(5) saling memenuhi kebutuhan, sehingga tidak ada kebutuhan salah satu pihak yang tidak terpenuhi

\section{Pengertian Sosial Ekonomi Orang Tua}

A.sorokin mengatakan bahwa "lapisan sosial adalah perbedaan penduduk atau masyarakat dalam hal ini peran atau keriteria yang biasanya dipakai untuk menggolongkan anggota masyarakat kedalam lapisan-lapisan sosial. 
Sedangkan kata ekonomi berasal dari kata yunani, yaitu "oikos" yang berarti segala sesuatu yang berhubungan dengan rumah tangga dan "nomos" yang berarti undang-undang / peraturan. Selanjutnya Mamangsangadji mengemukakan bahwa yang dimaksud dengan tingkat status sosial ekonomi adalah gambaran tentang keadaan seseorang atau suatu masyarakat yang di tinjau dari sosial ekonomi.

\section{Motivasi Siswa}

\section{a. Pengertian Motivasi}

Motivasi berasal dari kata "motive" yang mempunyai arti dorongan. M.C. Donal berpendapat seperti yang dikutip oleh (Drs. H. Nashar, 2004:13) bahwa: "motivasi adalah suatu perbuatan energi dalam diri seseorang yang ditandai dengan timbulnya perasaan dan reaksi mencapai tujuan". Motivasi bukan saja menggerakkan tingkahlaku, tanpa motivasi juga mengarahkan serta memperkuat tingkah laku (Ngalim Purwanto, 1986:69), motivasi berprestasi dalam pelajaran ekonomi adalah termasuk motivasi interaksi, yaitu faktor pendorong motivasi yang berasal dari diri siswa.

b. Aspek-aspek Motivasi

(1) Sikap Percaya Diri

Brown berpendapat seperti yang dikutif oleh Sudhe (1991) bahwa: "rasa percaya diri merupakan aspek prilaku manusia yang paling mendasar, keyakinan terhadap kemampuan diri adalah juga merupakan faktor yang mempengaruhi prestasi belajar siswa. Keyakinan adalah termasuk salah satu faktor internet yang mempengaruhi prestasi belajar ekonomi siswa".

(2) Budaya Kompetisi

Dalam menarik suatu kesuksesan atau keberhasilan, kita dapat mengatasi proses tercapainya keberhasilan dalam dunia bisnis dan olahraga yaitu diterapkannya pola budaya kompetisi. Menurut Soejono (1993:3) budaya kompetisi tersebut dikembangkan di sekolah khususnya dalam kegiatan proses belajar mengajar, mengingat rasa persaingan atau kompetisi itu sendiri sebenarnya sudah ada dalam diri siswa.

(3) Fungsi Motivasi

Menurut Sjahminan Zaini dalam Liliana Kurniawati (2010 : 8). Ada tiga fungsi motivasi : 
a. Mendorong manusia untuk berbuat, jadi sebagai penggerak atau motor yang melepas energi. Motivasi dalam hal ini merupakan motor penggerak dari setiap kegiatan yang akan dikerjakan.

b. Menentukan arah perbuatan. Yakni ke arah yang hendak ingin dicapai. Dengan demikian mitivasi dapat memberikan arah dari kegiatan yang harus dikerjakan dengan perbuatan-pebuatan yang harus dikerjakan yang serasi guna mencapai tujuan dengan menyisihkan perbuatan-perbuatan yang tidak bermanfaat bagi tujuan tersebut.

c. Macam-macam motivasi

Ada dua macam motivasi yaitu motivasi instrinsik dan ekstrinsik:

1. Motivasi instrinsik adalah motivasi yang terkandung di dalam perbuatan itu sendiri.umpama anak di dorong oleh keinginan untuk mengetahuinya. Di dalam belajar itu telah terkandung hal menam pengetahuan.

2. Motivasi ekstrisik merupakan motivasi yang terletak di luar perbuatan. Umpamanya belajar untuk mencari penghargaan berupa hadiah, ajazah dan sebagainya.

\section{Metode Penelitian}

\section{A. Jenis Penelitian}

Metode yanag digunakan dalam penelitian ini adalah metode deskriptif, yaitu studi yang bertujuan untuk mendeskripsikan atau menjelaskan peristiwa atau kejadian yang sedang berlangsung pada saat penelitian tanpa menghiraukan sebelum dan sesudahnya (Ridwan, 2005:27). Data yang diperoleh kemudian di peroleh kemudian diolah ditapsirkan dan disimpulkan.

Pendekatan yang digunakan adalah pendekatan kuantitatif yaitu suatu proses menemukan pengetahuan yang menggunakan data yang berupa angka sebagai alat menemukan keterangan mengenai apa yang ingin kita ketahui (sugiyono, 2008:13). Sedangkan (Arikunto,2006:11) mengungkapkan pendekatan kuantitatir adalah pendekatan yang banyak menuntut untuk menggunakan angka, mulai dari pengumpulan data, penapsiran terhadap data tersebut, serta penapsiran dari hasilnya. 
Data yang dikemukakan adalah data yang berbentuk angka-angka dengan menggunakan analisis statistik parametrik yang menghubungkan antara tiga variabel, yakni kepribadian guru dan sosial ekonomi orang tua dengan motivasi belajar siswa.

\section{B. Populasi dan Sampel Penelitian}

\section{Populasi Penelitian}

Populasi adalah totalitas semua nilai yang mungkin hasil menghitung atau hasil mengukur kuantitatif maupun kualitas dan karakteristik tertentu mengenai sekumpulan objek yang lengkap dan jelas (sudjana, 2002 ; 6). Ahli lain mengatakan populasi adalah keseluruh subjek penelitian yang mencakup semua elemen yang ada dalam walayah penelitian (suharsimi, $2002:$ 108).

Populasi dalam penelitian ini adalah semua kelas VIII MTs. NW Selebung yaitu 47 siswa yang berasal dari VIIIA sebnyak 22 dan VIIIB sebanyak 25 siswa.

\section{Sampel Penelitian}

Sampel adalah bagian dari populasi yang diambil dan dipergunakan untuk penelitian yang sifat dan karakteristiknya dapat mewakili populasi sebagai subyeknya (Tim Sosiologi, 2002:34). "Sampel adalah bagian dari populasi yang benar-benar diteliti atau diamati”. (M. Cholik Adinawan, 2005: 115).

Sampel adalah bagian dari jumlah atau karakteristik yang dimiliki oleh populasi tersebut (Sugiono, 2003:91).

Salah satu syarat utama dari sampel yang baik adalah harus mencerminkan ciri-ciri atau sifat-sifat yang terdapat pada populasi. Dengan kata lain sampel yang baik adalah sampel yang representatif atau mencermin-kan ciri-ciri populasi.

Berikut ini adalah tabel keadaan siswa kelas VIII A MTs. NW Selebung yang dijadikan sampel penelitian. Adapun pengambilan sampel ini random sampling, teknik ini digunakan dengan pertimbangan bahwa kelas VIII A merupakan kelas yang mempunyai masalah dalam proses pembelajaran dan siswa sulit memahami materi yang disampaikan oleh guru.

\section{Jenis dan Sumber Data}

1. Jenis data

Dalam penelitian ini ada dua jenis data yaitu

a. Jenis data kualitatif yaitu jenis data yang berhubungan dengan nilai, misalnya baik buruk, indah jelas, tinggi rendah dan sebagainya. 
b. Jenis data kuantitatif yaitu jenis data yang berhubungan dengan bilangan angka.

Sumber data penelitian ini ada dua yakni sebagai berikut:

a. Sumber data primer adalah sumber yang memberikan data langsung dari pertama

b. Sumber data skunder adalah sumber yang mengutip dari sumber lain.

Jadi sumber data primer dalam penelitan ini adalah nilai angket yang disebarkan kepada siswa kelas VIII MTs NW Selebung, sedangkan sumber data skunder adalah berupa nilai rapot siswa semester II kelas VIII MTs NW Selebung yang dijadikan sebagai responden yang diperoleh melalui metode dokumenstrasi.

\section{Tehnik dan Instrumen Pengumpulan Data}

\section{Tehnik Pengumpulan Data}

a. Angket

Metode angket adalah daftar pertanyaan yang diberikan kepada orang lain yang bersedia memberikan respon sesuai dengan permintaan pengguna. Janis angket yang digunakan dalam penelitian ini adalah angket tertutup yaitu yang disajikan dalam bentuk sedemikian rupa sehingga responden diminta untuk memilih satu jawaban yang sesuai dengan karakteristiknya dengan cara memberikan tanda silang (x).

\section{b. Observasi}

Metode ini dilakukan untuk mengamati kegiatan belajar di sekolah dengan kebiasaan mendengarkan, memandang, membaca, membuat ringkasan, latahan dan peraktik di dalam mengikuti proses belajar mengajar baik disaat jam pelajaran di sekolah maupun belajar di rumah.

\section{Instrumen Pengumpulan Data}

Data yang diperoleh dari penelitian ini adalah data primer yang dikumpulkan langsung oleh peneliti melalui kuisioner dari sampel yang telah dipilih. Kuisioner tersebut merupakan seperangkat pertanyaan atau pernyataan yang diterangkan sendiri oleh peneliti. 


\section{E. Teknik Dan Alat Analisis Data}

\section{Teknik Analisis Data}

Data yang dipaeroleh dideskripsikan dengan menggunakan statistik deskriptif. Statistik deskriptif ini meliputi penentuan skor rata-rata atau mean $(\bar{X})$ dan standar deviasi (SD) untuk keperluan menyusun tabel konversi terlebih dahulu dicari Mean Ideal (Mi) dan Standar Deviasi Ideal (SDi) dengan rumus sebagai berikut:

$$
\begin{array}{r}
\mathrm{Mi}=1 / 2(\text { Skor maksimal }+ \text { skor minimal ideal }) \\
\mathrm{SDi}=1 /{ }_{6}(\text { skor maksimal ideal }+ \text { skor minimal ideal }) \\
\text { (I Nyoman Dantes, 1993:45). }
\end{array}
$$

\section{a. Deskripsi Data}

Dalam rangka mengolah data-datanya dapat dipergunakan metode "analisis statistic" seperti pendapat Sanafiah dalam Indring Fispiana (2001 : 28) yang mengatakan statistik adalah seperangkat teknik untuk mengumpulkan data angka.

\section{b. Uji Validitas dan Reabilitas}

a. Uji validitas

Validitas adalah suatu ukuran yang menunjukkan tingkat kevalitan dan kesahihan suatu instrument. Suatu instrumen yang valid sudah mempunyai validitas tinggi, sebaliknya instrument yang kurang valid berarti memiliki validitas rendah (Suharsimi, 2002:144).

b. Uji Reliabilitas

Reliabilitas menunjukkan pada suatu pengertian bahwa suatu instrument cukup dapat dipercaya untuk dapat digunakan sebagai alat pengumpul apabila instrumen tersebut sudah baik instrumen yangbaik tidak akan bersifat tendensius yang mengarahkan seorang responden untuk memilih jawaban tertentu (Suharsimi Arikunto, 2002:189).

\section{c.Uji Persyaratan Analisis Data}

\section{Uji Normalitas Data}

Uji normalitas data digunakan untuk mengetahui normal atau tidaknya data yang menjadi syarat untuk menentukan jenis statistik apa yang digunakan dalam analisis lebih lanjut. 
ktiteria "jika harga $\mathrm{X}^{2}$ hitung $<\mathrm{X}^{2}$ tabel maka data yang diperoleh berdistribusi normal dan jika harga $\mathrm{X}^{2}$ hitung $>\mathrm{X}^{2}$ tabel maka data yang diperoleh tidak berdistribusi normal( Arikunto,2006:259).

\section{d. Teknik Uji Hipotesis}

Hipotesis adalah pernyataan yang diterima secara sementara sebagai suatukebenaran sebagai mana adanya dari suatu fenomena- fenomena yang komplek. (Nazir,2003:151).

\section{e.Uji hipotesis dengan menggunakan t-test}

Uji t-test digunakan untuk mengetahui hubungan dan pengaruh secara varsial atau sendiri- sendiri dari variabel bebas terhadap variabel terikat.

\section{HASIL PENELITIAN DAN PEMBAHASAN}

\section{A. Hasil Penelitian}

\section{Deskripsi Data}

a. Variabel Kepribadian Guru

Berdasarkan data yang dikumpulkan diperoleh skor terendah 43 dan skor tertinggi 57 dari perhitungan terhadap data tersebut diperoleh mean $(\mathrm{M})=$ 46,59 dan standar deviasi (SD) $=3,57$, maka secara umum dapat digolongkan bahwa data skor variabel kepribadian guru di MTs NW Selebung termasuk kategori tinggi.

b. Variabel Sosial Ekonomi Orang tua

Berdasarkan data yang dikumpulkan diperoleh skor terendah 40 dan skor tertinggi 54 dari perhitungan terhadap data tersebut diperoleh mean $(\mathrm{M})=$ 44,95 dan standar deviasi (SD) =4,68 dan Mean yang diperoleh yakni 44,95 dalam kategori di atas, maka secara umum dapat digolongkan bahwa data skor variabel sosial ekonomi orang tua di MTs NW Selebung termasuk kategori sedang. 
c. Variabel motivasi belajar siswa

Berdasarkan data yang dikumpulkan diperoleh skor terendah 38 dan skor tertinggi 52 dari perhitungan terhadap data tersebut diperoleh mean $(\mathrm{M})=$ 47,5 dan standar deviasi $(\mathrm{SD})=4,22$

Sementara berdasarkan data variabel kepribadian guru dicari pula skor maksimal, skor minima, harga rata-rata dan standar deviasi ideal) dan standar rata-rata ideal (Mi). dan Mean yang diperoleh yakni 47,05 dalam kategori di atas, maka secara umum dapat digolongkan bahwa data skor variabel motivasi belajar siswa di MTs NW Selebung termasuk kategori tinggi.

\section{Uji Normalitas Data}

a. Data variabel kepribadian guru

Dari perhitungan data diperoleh harga $\mathrm{X}_{\text {hitung }}^{2}=4,98$ dan diberikan interprestasi terhadap chi kuadrat tersebut $\mathrm{dk}=(\mathrm{k}-1)$ jumlah jalur yang kita miliki 5 buah sehingga $\mathrm{dk}=5-1=4$ dengan $\mathrm{dk}=4$ diperoleh harga chi kuadrat pada tabel dengan taraf nyata $95 \%$ adalah $\mathrm{X}_{\text {tabel }}^{2}=11,070$ yang berarti $\mathrm{X}_{\text {hitung }}^{2}<\mathrm{X}_{\text {tabel }}^{2}$ atau 4,98<11,070. Dengan demikian dapat dikatakan bahwa variabel kepribadian guru tergolong berdistribusi normal.

b. Data variabel ekonomi orang tua

Dari perhitungan data diperoleh harga $\mathrm{X}_{\text {hitung }}^{2}=2,421$ dan diberikan interprestasi terhadap chi kuadrat tersebut $\mathrm{dk}=(\mathrm{k}-1)$ jumlah jalur yang kita miliki 5 buah sehingga $\mathrm{dk}=5-1=4$ dengan $\mathrm{dk}=4$ diperoleh harga chi kuadrat pada tabel dengan taraf nyata $95 \%$ adalah $\mathrm{X}_{\text {tabel }}^{2}=11,070$ yang berarti $\mathrm{X}_{\text {hitung }}^{2}<\mathrm{X}_{\text {tabel }}^{2}$ atau 2,421 < 11,070. Dengan demikian dapat dikatakan bahwa variabel sosial ekonomi orang tua tergolong berdistribusi normal.

c. Data variabel motivasi belajar siswa

Dari perhitungan data diperoleh harga $\mathrm{X}_{\text {hitung }}^{2}=1,457$ dan diberikan interprestasi terhadal chi kuadrat tersebut $\mathrm{dk}=(\mathrm{k}-1)$ jumlah jalur yang kita miliki 5 buah sehingga $\mathrm{dk}=5-1=4$ dengan $\mathrm{dk}=4$ diperoleh harga chi kuadrat pada tabel dengan taraf nyata $95 \%$ adalah $\mathrm{X}_{\text {tabel }}^{2}=11,070$ yang berarti $\mathrm{X}_{\text {hitung }}^{2}<\mathrm{X}_{\text {tabel }}^{2}$ atau 1,457<11,070. Dengan demikian dapat dikatakan bahwa variabel motivasi belajar siswa tergolong berdistribusi normal. 


\section{Hasil analisis korelasi dan regresi benda untuk $X_{1}$ dan $X_{2}$ dengan $Y$}

Pada bagian ini akan diinterprestasikan hasil pengujian hipotesis dengan rincian sebagai berikut:

a. Ada hubungan yang signifikan antara kepribadian guru dengan sosial ekonomi orang tua

Besarnya hubungan antara variabel kepribadian guru $\left(\mathrm{X}_{1}\right)$ dengan variabel sosial ekonomi orang tua $\left(\mathrm{X}_{2}\right)$ yang dihitung dengan koefisien korelasi adalah 1,032 atau rxy $=1,032$. Hal ini menunjukkan hubungan yang kuat antara variabel kepribadian guru dengan sosial ekonomi orang tua. Sedangkan tingkat signifikansi koefisien korelasi 1 sisi dari output (diukur dari probabilitas) menghasilkan angka 0,00. Karena probabilitas jauh di bawah 0,05 maka korelasi antara variabel kepribadian guru dengan sosial ekonomi orang tua adalah signifikan.

b. Ada pengaruh yang signifikan antara kepribadian guru terhadap motivasi belajar siswa

Berdasarkan bahwa besarnya pengaruh antara variabel kepribadian guru $\left(\mathrm{X}_{1}\right)$ dengan variabel motivasi belajar siswa $(\mathrm{Y})$ yang dihitung dengan koefisien korelasi adalah 0,932 atau rxy $=0,932$. Hal ini menunjukkan hubungan yang kuat antara variabel kepribadian guru dengan motivasi belajar siswa. Sedangkan tingkat signifikansi koefisien korelasi 1 sisi dari output (diukur dari probabilitas) menghasilkan angka 0,00. Karena probabilitas jauh di bawah 0,05 maka korelasi antara variabel kepribadian guru dengan motivasi belajar siswa adalah signifikan.

Dari uji anova atau F-tes ternyata didapat F-hitung $=7,73$ denan tingkat signifikansi 0,00. Karena probabilitas $(0,00)$ jauh lebih kecil dari 0,05. Sehingga modul regresi dapat dipakai untuk memprediksi motivasi belajar siswa. Dari lampiran 15 juga menggambarkan bahwa persamaan regresi sebagai berikut : $\mathrm{y}=\mathrm{a}+\mathrm{b}_{1} \mathrm{x}_{1}=44,9$ $+0,009 \mathrm{x}_{1}$.

Konstanta sebesar 4,49 menyatakan bahwa jika tidak ada kenaikan nilai dari variabel kepribadian guru $\left(\mathrm{x}_{1}\right)$, maka nilai motivasi belajar siswa (y) adalah 44,9. Koefisien korelasi sebesar 44,9 + 0,009 menyatakan bahwa setiap penambahan (karena tanda + ) satu skor atau penilaian kepribadian guru akan memberikan pembahana skor sebesar $+0,009$. 
Sedangkan hasil pengujian signifikansi antara variabel kepribadian guru dengan variabel motivasi belajar siswa menggunakan uji-t berdasarkan hasil perhitungan (lampiran 16) di dapat bahwa t-hitung $(0,392)<\mathrm{t}$-tabel $(1,723)$ pada taraf signifikansi 0,05, maka Ho ditolak dan Ha diterima, artinya koefisen regresi signifikan secara signifikan terhadap motivasi belajar siswa atau lebih

\section{b. Pembahasan Hasil Penelitian}

Berdasarkan pengelolaan dan analisis data diperoleh hasil uji normalitas data $\left(\mathrm{X}^{2}\right)$ variabel kepribadian guru $=4,928$ dan variabel sosial ekonomi orang tua $=2,421$ serta motivasi belajar siswa $=1,457$ dengan $\mathrm{X}^{2}$ tabel $=11,070(\mathrm{pada} a=0,05)$ dengan kriteria jika X2 hitung $<$ X2 tabel maka data berdisribusi normal.

Pada pengujian hipotesis, ketiga hipotesis alternatif $(\mathrm{Ha})$ yang diajukan adalah

1. Terdapat hubungan yang signifikan antara kepribadian guru dan sosial ekonomi orang tua dengan nilai koefisien korelasi $r=1,032$. ini ditandai dengan adanya interpretasi koefisien korelasi antara 0,80 - 1,032 memiliki tingkat hubungan yang sangat kuat.

2. Ada pengaruh yang signifikan antara kepribadian guru dan motivasi belajar siswa ditandai dengan $\mathrm{t}$ hitung $<\mathrm{t}$-tabel atau $0,392<1,723$. Artinya terdapat pengaruh yang signifikan antara kepribadian guru dengan motivasi belajar siswa dengan taraf kepercayaan 0,05 dengan arah regresi $\mathrm{y}=44,9+0,009 \mathrm{X}_{1}$.

3. Ada pengaruh yang signifikan antara sosial ekonomi orang tua dengan motivasi belajar siswa diterima dengan t-hitung $>$ t-tabel atau 18,167<1,723. Artinya terdapat pengaruh yang signifikan antara sosial ekonomi orang tua dengan motivasi belajar siswa dengan taraf kepercayaan 0,05 dengan arah regresi $\mathrm{y}=44,9$ $+0,05 \mathrm{X}_{2}$.

4. Ada pengaruh yang signifikan secara simultan antara kepribadian guru dan sosial ekonomi orang tua terhadap motivasi belajar siswa ternyata diterima artinya terdapat pengaruh yang signifikan antara kepribadian guru dan sosial ekonomi orang tua terhadap motivasi belajar siswa di MTs NW Selebung. Ini dibuktikan bahwa harga F-hitung $>$ F-tabel atau 7,73 > 3,81 pada taraf kepercayaan 95\% dengan $\mathrm{dk}$ pmbilang $2 \mathrm{dan} \mathrm{dk}$ penyebut $(\mathrm{n}-\mathrm{m}-1)=19$ dengan arah regresi ditandai dengan $\mathrm{t}$ hitung $<\mathrm{t}$-tabel atau $0,392<1,723$. Artinya terdapat pengaruh 
yang signifikan antara kepribadian guru dengan motivasi belajar siswa dengan taraf kepercayaan 0,05 dengan arah regresi $\mathrm{y}=44,9+0,009 \mathrm{X}_{1}+0,05 \mathrm{X}_{2}$.

\section{Kesimpulan}

Dari hasil pengumpulan data yang telah diambil, untuk selanjutnya diadakan analisis data, maka dapat ditarik suatu kesimpulan sebagai berikut:

Pertama, variabel kepribadian guru di MTs NW Selebung termasuk kategori tinggi dengan nilai mean (M) 46,59 dan standar deviasi $) \mathrm{SD}$ ) $=3$,17. dan variabel sosail ekonomi orang tua di MTs NW Selebung termasuk kategori tinggi dengan nilai mean $(M)=44,95$ dan standar deviasi $(S D)=4,68$. Sedangkan variabel motivasi belajar ssiwa di MTs. NW Selebung termasuk kategori tinggi juga dengan nilai mean (M) $=47,5$ dan standar deviasi S(D) 4,22.

Kedua, variabel kepribadian guu di MTs. NW Selebung termasuk skor daa normal dengan nilai $\mathrm{X} 2$ hitung $=4,928$ dam variabel sosial ekonomi orang tua di MTs NW Selebung memiliki skor data normal dengan nilai X2 hitung $=2,421$. sedangkan variabel motivasi belajar siswa di MTs NW Selebung juga memiliki skor data normal dengan nilai X2 hitung $=1,457$ termasuk dalam kategori tinggi dengan nilai Mean $(M)=47,5$ dan standar deviasi $(S D)=4,22$. dengan $\mathrm{X} 2$ tabel $=11,070$ pada taraf kepercayaan $95 \%$.

Ketiga, bahwa terdapat pengaruh yang signifikan antara kepribadian guru dan sosial ekonomi orang tua terhadap motivasi belajar siswa di MTs NW Selebung. Hal ini dapat dilihat dari hasil perhitungan terhadap uji hipotesis dengna menggunakan regresi ganda dengan nilai $\mathrm{RX}_{1} \mathrm{X}_{2} \mathrm{Y}=0,29$ kemudian dikonsultasikan dengan $\mathrm{F}$ hitung sebesar $(7,73)$ dan Ft-tabel 3,81 pada tarf kepercayaan 5\% dan dk pembilang $(\mathrm{m})=2$ dan dk penyebut (n-m-1) 19 ata dengan kata lain F-hitung $>$ F-tabel atau $(7,73>3,81)$ dengan arah regresi $y=44,9+0,009 \mathrm{X}_{1}+0,05 \mathrm{X}_{2}$. 


\section{Daftar Pustaka}

Amsrdain Indra Kusuma. 1999. Penghantar Ilmu Pendidikan, Usaha Nasional.

Arikunto, Suharsimi. 2002. Prosedur Penelitian. PT. Rineka Cipta , Jakarta

Hasan, Iqbal. 2001. Pokok-Pokok Materi Statistik I. Jakarta: Bumi Aksara. 2001. Pokok-Pokok Materi Statistik II. Jakarta: Bumi Aksara. 2004. Analisis Datas Penelitian dalam Statistik. Jakarta: Bumi Aksara.

Margono. 2007. Metodologi Pendidikan. Jakarta: PT. Rineka Cipta

Nashar. H. 2004. Peranan Motivasi Dan Kemampuan Awal Dalam Kerataan Pembelajaran. Delia Joress, Jakarta,

Ngalim Purwanto. 1988. Psikologi Pendidikan, Remaja Karya Bandung

Ongkoswara. tt. Kurikulum Usaha-Usaha Perbaikan Dalam Bidang Pendidikan Dan Administrasi Pendidikan. Depdikbut, NV.

Rohani, Ahmad. 2004. Pengelolaan Pengajaran. Jakarta: PT. Rineka Cipta

Sadia, Wayan. 2002. Konstruktivisme Dalam Belajar Mengajar (Hand Out Materi Perkuliyah Landasan Pembelajaran Program S 2 Penelitian Dan Evaluasi Pendididikan IKIP Negeri Singaraja)

Sudjana, 2002. Metode Statistik, Tarsito, Bandung

Sugiono. 2006. Metode Penelitian Pendidikan. Bandung: alfabet

Suharto Juniarti. 1990. Metodologi Pengajaran, IKIP Jakarta

Sudjana. 2002. Metode Statistik. Tarsito, Bandung 